\title{
Infogate Influences on Reforms of South Africa's Intelligence Services
}

\section{Glen Segell}

Department of Political Studies and Governance, University of the Free State, South Africa, http://www.ufs.ac.za

\begin{abstract}
The hypothesis is that intelligence reform and intelligence sector reform result from traumatic catalyst rather than gradual evolution, reactionary rather than proactive, and not soon or quickly. The threat environment, an emergency, a necessity, e.g., democratization, gross failure, and scandals, are causes for reforms. The case is South African intelligence services. South Africa is significant due to diverse and constantly changing operational environments: the Cold War, decolonization of Africa, apartheid, post-Cold war, and post-Apartheid democratization. From the first nonmilitary intelligence agency created in 1968, the Bureau of State Security, it was clear the nature of intelligence was such that the balance between secrecy, transparency, and accountability would always be a fine one to strike. The relationship between the political echelons, e.g., the Prime Minister and the Bureau's Director, was too close and so allowed misuse of state funds. The uncovering of the abuse of state funds, the Infogate scandal, had an influence on subsequent reforms, including those for democratization to abolish apartheid and introduce a "one-man, one-vote democracy," achieved in 1994. Reforms through legislation, jurisdictions, restructuring, micro-managing intelligence, merging apartheid and opposition intelligence services, and creating post-apartheid intelligence services are examined in this article. The experience teaches us that errors can be avoided by not making uncoordinated, piecemeal changes; every reform is unique and rarely easy; operationalizing legislative mandates of transformation is more difficult than anticipated. The reform process starts with reflecting the envisaged ideal situation, yet the outcome is not always as expected and thus requires more reforms.
\end{abstract}

Keywords: South Africa, Infogate, intelligence reforms, intelligence sector reforms, democratization, Cold War, Apartheid. 


\section{Introduction}

The hypothesis underlying this article is that intelligence reform and intelligence sector reform tend to result from traumatic catalyst rather than gradual evolution. Hence, reforms are more reactionary than proactive. Unless there is a specific necessity, then reform will not happen soon, quickly, or ever. Typically, an intelligence agency is created due to the threat environment or an emergency and is disbanded as a result of a change in the threat environment. Among other necessities are, for example, democratization, a gross failure, or a scandal.

This hypothesis is examined in the case of the South Africa intelligence services. There has been continuous reform due to a changing threat environment, for example, decolonization in Sub-Saharan Africa, the Cold War, the Apartheid era, and the post-Cold war and post-Apartheid eras. They went hand-in-hand with introducing a "one-man, one-vote democracy" that was achieved in 1994. The reforms examined in separate sections in this article involve changes in legislation and jurisdictions, restructuring, micro-managing intelligence, merging apartheid and opposition intelligence services, and creating post-Apartheid intelligence services.

The premises of the hypothesis were evident from the onset with the creation of the first non-military intelligence agency in 1968, the Bureau of State Security (BOSS). From the onset, it was also apparent that the nature of intelligence was such that the balance between secrecy, transparency, and accountability would always be a fine one to strike. The relationship between the political echelons, including the Prime Minister and BOSS's Director, were too close and so allowed state funds to be misused.

An intelligence service must not influence government policy, engage in acts of surveillance of the population and violence en mass, violate citizens' rights and abuse them, and misuse state funds. For in a democracy, the intelligence services should serve the state and not the opposite. Yet, this is what happened in BOSS. Maybe because South Africa under Apartheid (1948-1994) was not a democracy. Most of its citizens who were non-white were denied through legislation to elect or be elected. There was no accountability and transparency of government activities, actions, and the use of state funds that are usually to be found in a democracy.

The uncovering of the misuse of state funds is known as the Infogate scandal. All subsequent reforms, including those to suit new operational environments and democratization, were all influenced by the trauma of this gross misconduct. The following reforms had the transparency in the use of state funds as their key element and aimed to make the intelligence sector more accountable for its actions and activities.

The lessons from creating BOSS and subsequent reforms (1968-1998) are that every reform is unique. Reform is almost never easy. In tense situations that require reforms, errors can be avoided by not making uncoordinated, piecemeal changes. Operationalizing any changes that include legislative mandates of transformation is always more difficult than anticipated. There are no good 
sources about the future, so while the process to be addressed in reform starts with reflecting the envisaged ideal situation, the outcome is not always expected. And while there was a linked process of democratization to end apartheid, with that of intelligence reform and intelligence sector reforms, they should have begun earlier rather than later.

\section{Intelligence Services Requirement}

The Union of South Africa was formed in 1910, in the aftermath of the AngloBoer War (1899-1902), by merging two former British colonies, the Cape and Natal, and two independent states, The Transvaal and the Orange Free State. The National Party won the post-World War II elections and introduced in 1948 a legislated system of racial segregation known as the Apartheid Laws. In 1961 the National Party declared South Africa a Republic and left the British Commonwealth. The Apartheid was a political system with the legislated white rule only by descendants of European settlers and the subjugation of all indigenous nonwhite people, who did not have the right to elect or be elected. ${ }^{1}$

The South African security services were entrusted with enforcing the Apartheid policies. Their activities, successes, and failures were in part shaped by the de-colonial process faced by neighboring states in sub-Saharan Africa and by the Cold War. South Africa was rationalized as being in the Western Bloc because it was not communist and because it was fighting counter-insurgency campaigns against Eastern Bloc forces. Yet, South Africa had little or nothing in common with other Western Bloc countries and had no formal treaty ties. It was capitalist but not democratic because of apartheid. ${ }^{2}$

Western states friended South Africa because it was located geo-strategically at the southern tip of Africa where the Atlantic and Indian Oceans meet. Its sea routes and ports were of strategic importance for Western Europe and North America for trading with the Far East because the large oil tankers from the Middle East could not navigate the Suez Canal, and during Middle East wars, the Suez Canal was closed. ${ }^{3}$

South Africa was fighting against Eastern Bloc-supported forces domestically and externally. Domestically for the anti-Apartheid movement was supported by the Eastern Bloc. The Soviet view was that Apartheid was Imperialist. So, antiApartheid forces such as the African National Congress (ANC) were sponsored by the Eastern Bloc as a colonial struggle. These forces conducted guerrilla and terrorist activities within South Africa from 1961 until the end of apartheid in 1994

1 Roger B. Beck, The History of South Africa (Westport, CT: Greenwood Press, 2013), 310.

2 William Blum, West-Bloc Dissident: A Cold War Political Memoir (New York: Soft Skull Press, 2001), 190.

3 Irina Filatova and Apollon Davidson, The Hidden Thread: Russia and South Africa in the Soviet Era (Johannesburg: Jonathan Ball, 2013), 23. 
as part of the freedom movement struggle. There was active Soviet Union involvement, for example, led by KGB Colonel Joe Slovo. South Africa went so far as to attempt to assassinate him but only succeeded in killing his wife, Ruth. ${ }^{4}$

South Africa was also fighting against Eastern Bloc communist forces externally, for example, against Cuban and East German troops and the local forces that they supported in the de-colonial independence struggles in the neighboring states of Angola, Mozambique, and Rhodesia (now Zimbabwe). The aim of the involvement of the South African security services in the regional sub-Saharan Africa conflicts was to create buffer zones against encroaching communist forces aimed at toppling the Apartheid regime. ${ }^{5}$

\section{The Birth of the Intelligence Service BOSS}

In 1963, Mr. B.J Vorster, the Justice Minister under Prime Minister H.F. Verwoerd, examined the option to form South Africa's first non-military intelligence agency in addition to its small military intelligence gathering capability. There was growing resistance against apartheid, for example, the Sharpeville incident in 1961. ${ }^{6}$ After Voster became Prime Minister in 1966, there were the first skirmishes between South African military forces and Eastern Bloc forces in the Caprivi Strip bordering Angola and South-West Africa (now Namibia).

Based on these perceived security needs, both domestically and externally, the South African Cabinet approved in 1968 the implementation of a new centralized security service called the Bureau of State Security (BOSS). Its first Director would be General Hendrik van den Bergh of the South African Police Security Branch. He was a close confidant of Prime Minister Voster since the 1940s. He was also appointed as Security Advisor to Vorster. Attached to the Prime Minister's office, he would be in command of all security and intelligence chiefs in the country, including the military, and report only to Vorster.

BOSS became more than an intelligence service and was well known for atrocities. Although van den Bergh denied BOSS's use of hit squads against its enemies, he is nevertheless remembered for sanctioning the use of torture, assassinations, and other tactics against the government's enemies, and he once told a government commission, "I have enough men to commit murder if I tell them to kill. I don't care who the prey is. These are the type of men I have." 7

4 Alan Wieder, Ruth First and Joe Slovo in the War Against Apartheid (Auckland Park, South Africa: Jacana, 2013), 57.

5 Chris Saunders, "South Africa's War, and the Cuban Military, in Angola," Journal of Southern African Studies 40, no. 6 (2014), 1363-1368, https://doi.org/10.1080/0305 7070.2014.964933.

6 Ron Nixon, Selling Apartheid: South Africa's Global Propaganda War (London: Pluto Press, 2016), 12-14.

7 Peter Parker and Joyce Mokhesi-Parker, In the Shadow of Sharpeville: Apartheid and Criminal Justice (London: Palgrave Macmillan, 1998), 121. 


\section{The First Reform: Legislation}

On May 13, 1969, Minister of the Interior S.L. Muller introduced the framework of BOSS in the "Public Service Amendment Bill (1969)," which he said was responsible only for "coordination" and would draw personnel from other security and intelligence organizations. It outlined that BOSS's control would rest with the Prime Minister and that the civil service Public Service Commission would have no control over its powers, functions, and duties. ${ }^{8}$

The data shows that the release of the expenditures for the next Tax Year April 1969/ April 1970 saw an increase of $188 \%$ over the previous year to BOSS. On the other hand, Military Intelligence's (MI) budget was reduced from the previous year by two-thirds. This led to a publicized struggle between MI and BOSS. ${ }^{9}$ To hide this, a week later, the "Security Services Special Account Bill (1969)" was passed, which saw the use of money allocated to BOSS as confidential. This effectively halted the public feud and ensured that BOSS would not be subject to an audit by the Auditor-General as other government departments. ${ }^{10}$

Moreover, the "General Law Amendment Bill (1969)" was passed that prevented the Prime Minister, van den Bergh or cabinet ministers from giving evidence or producing documents in court that might prejudice state security. This caused outrage throughout the South African legal community, who considered that it could no longer protect citizen's rights from the Government executive. ${ }^{11}$

\section{The Second Reform: Jurisdictions}

Perhaps because of this outrage on September 5, 1969, Prime Minister John Vorster announced the formation of a commission led by Justice H.J. Potgieter to establish the guidelines and mission for BOSS. In practice, however, the "Commission to Inquire into Certain Intelligence Aspects of State Security," known better as the Potgieter Commission, was only tasked to investigate the clashes between BOSS and $\mathrm{MI}$ and define who had primary responsibility for intelligence gathering in South Africa. ${ }^{12}$

8 South African Government, "Public Service Amendment Bill (1969)," accessed September 3, 2020, http://www.saflii.org/za/cases/ZARMC/1969/2.pdf.

9 Alex Hepple, "South Africa's Bureau for State Security," The World Today 25, no. 10 (October 1969), 436-439.

10 South African Government, "Security Services Special Account Act 81 of 1969," accessed September 3, 2020, https://www.gov.za/documents/security-services-specialaccount-act-20-may-2015-1043.

11 South African Government, "General Law Amendment Act 101 of 1969," accessed September 3, 2020, https://www.gov.za/documents/general-law-amendment-act20-may-2015-1017.

12 "Prime Minister John Vorster appoints a Commission of Inquiry under Justice H.J. Potgieter, of The Appellate Division of the Supreme Court," South African History Online, accessed September 3, 2020, http://www.sahistory.org.za/. 
The Potgieter Commission took its time and only reported back on February 2, 1972, leading to the "Security Intelligence and State Security Council Act (1972)." The Act would form the State Security Council under the control of the Cabinet and establish it as the government's national center for operational security. The BOSS head van den Bergh, who was a close ally of the Prime Minister, was favored by the Act giving him greater power beyond just overseeing a "coordinating service." It enabled him to influence all aspects of South Africa's policy on subversion, counterespionage, and political and economic espionage. ${ }^{13}$

By 1975 the anti-Apartheid movement intensified with increased Eastern Bloc support. The neighboring states of Angola and Mozambique that had been Portuguese colonies attained independence after a regime change in Portugal, and Rhodesia (now Zimbabwe) was in an all-out civil war. The government feared that South Africa would be next. The government was divided on how best to counter the Soviet involvement in Angola that threatened to spread south and into South Africa. Defense Minister P.W. Botha and the Chief of the Army General Magnus Malan advocated an all-out invasion into Angola to end the Soviet involvement. On the other hand, Prime Minister Vorster and General van den Bergh favored only a limited, covert operation into Angola. ${ }^{14}$

The latter option was chosen, though the South African military intervention in Angola failed. In sight of the Angolan capital, South African forces were repulsed by a fresh influx of Cuban troops. The United States, which had covertly backed the operation, was forced to withdraw its support when the American Congress vetoed the American President Ford administration's request for funding. As a result, South Africa was forced to withdraw from Angola and then faced a protracted counter-insurgency war in South West Africa that bordered Angola until the former became independent as Namibia in 1989. ${ }^{15}$

Although it was a military operation, BOSS became involved in the Angolan war. It should have been the role and task of Military Intelligence to handle all matters in that conflict. The BOSS involvement was understood because of the close relationship between van den Bergh, head of BOSS, and Prime Minister Vorster. This bothered the then Minister of Defense, P.W. Botha, as BOSS had become increasingly powerful to the point where it wielded more influence than both the Ministries of Defense and Foreign Affairs. ${ }^{16}$

13 "Security report by Justice H.J. Potgieter's Commission of Inquiry on State Security," South African History Online, accessed September 3, 2020, www.sahistory.org.za/.

14 Jannie Geldenhuys, At the Front: A General's Account of South Africa's Border War (Jeppestown: Jonathan Ball, 2009), 63-65.

15 Elaine Windrich, The Cold War Guerrilla: Jonas Savimbi, the U.S. Media and the AngoIan War (New York: Greenwood Press, 1992), 145.

16 James Barber and John Barratt, South Africa's Foreign Policy: The Search for Status and Security, 1945-1988 (Cambridge: Cambridge University Press, 1990), 327. 


\section{The Infogate Scandal}

The close relations of Prime Minister Voster to BOSS's van den Bergh led to the Infogate scandal. The scandal resulted from one of many strategies promoted and implemented by BOSS - engage in information operations, a propaganda war, both for apartheid and against the Eastern Bloc threat domestically and externally. The goal of the strategy was to influence the local and global media and hence the opinion of both public and political leadership. The ends were seen to be essential or even existential for these projects. The tactics, or means, would be to create front organizations and media projects.

The scandal was a greying of the lines of legality in the allocation of funds and the shifting of funds from the defense budget to BOSS. The illegality was the masking or covering of the funding from the normal governmental audit process, in sum, misappropriating and misusing state funds which BOSS had masked for secret front organizations and media projects. ${ }^{17}$

The change in the country's leadership would lead to a change in the entire scheme of such things. On October 2, 1978, B.J. Vorster resigned as Prime Minister to become State President. On October 9, 1978, Defense Minister P.W. Botha was appointed as the new Prime Minister. The decade-long struggle of roles and funding between BOSS and Military Intelligence would lead the former Defense Minister as the new Prime Minister to examine all aspects of BOSS. ${ }^{18}$

The issue that alarmed BOSS was the future of its clandestine projects and their funding. Fearing this, BOSS officials shredded any document that could be used against them. Despite this attempt, they would be unmasked due to another investigation. ${ }^{19}$

This investigation was initiated in the autumn of 1978 by the Minister of Finance, Owen Horwood, under the auspices of Judge Anton Mostert to probe exchange-control monetary violations. Justice Mostert informed the public of the scandal on November 3, 1978, with the newspaper heading "It's all True." The Rand Daily Mail newspaper broke the story of its opposition newspaper The Cit-

17 Graham Macklin, "The British Far Right's South African Connection: A.K. Chesterton, Hendrik van den Bergh, and the South African Intelligence Services," Intelligence and National Security 25, no. 6 (2010), 823-842, https://doi.org/10.1080/02684527.20 10.537879.

18 South African Government, South African Department of Information Scandal: Erasmus Commission of Inquiry, Reference FCO 105/175, The National Archives (TNA), Kew, United Kingdom.

19 C. Barron, "The Judge Was a Pawn in PW's Cover-up Bid," Sunday Times, Insight, April 25, 1999, 3. 
izen as being a government plot created using funding officially allocated to other purposes. ${ }^{20}$

Prime Minister Botha then instituted a judicial commission of inquiry into the whole affair of front organizations and masked funding under the chair of Mr. Justice Roelof Erasmus. The scandal was to culminate in the resignation of the State President, B.J. Vorster (former Prime Minister), and a Cabinet Minister, Dr. Connie Mulder. They, together with Dr. Eschel Rhoodie (Secretary of the Department of Information) and the chief of BOSS, General Hendrik van den Bergh were found to be the main protagonists in the illegal appropriation of state funds. In a spate of reforms due to the Infogate scandal, BOSS was replaced by the National Intelligence Service (NIS) in 1980. ${ }^{21}$

\section{The Third Reform: Restructuring}

In October 1978, Deputy Defense and Intelligence Minister Kobie Coetsee was appointed by Prime Minister PW Botha to lead a commission of inquiry into intelligence gathering and who would be the lead agency. Reforms introduced intended to overcome the challenges and issues of financial misappropriation and the close collusion of appointed and elected officials. ${ }^{22}$ Owing to trauma from the Infogate scandal, reviews, accountability and transparency, and division of authority would become a standard operating procedure for all subsequent reforms for the next 20 years.

The intelligence-gathering ability of BOSS was split amongst four agencies, the Department of Military Intelligence (DMI), a revised BOSS, the Security Branch of the Police, and various sections within the Foreign Affairs services. Yet, one dilemma was clear from the onset, that the rise of P.W. Botha to be Prime Minister was influenced by his former role as Minister of Defense. Accordingly, he wanted to see the South African Defence Force's (SADF) power increase in the Cabinet and, with that, the power of the Directorate Military Intelligence (DMI). ${ }^{23}$

The revised BOSS was brought under tighter control as a cabinet portfolio called National Security managed directly by Prime Minister Botha, who also held the Minister of Defense portfolio. He reformed BOSS into a new agency based around research and analysis and removed its covert operational function.

20 South African Government, South African Department of Information Scandal: Erasmus Commission of Inquiry, Reference FCO 105/175, The National Archives (TNA), Kew, United Kingdom.

21 South African Government, South African Department of Information Scandal.

22 Petrus Swanepoel, Really inside BOSS: A Tale of South Africa's Late Intelligence Service (South Africa: Derdepoortpark, May 2007), 17-19.

23 Chris Dempster, Dave Tomkins, and Michel Parry, Fire Power (London: Corgi Books, 1978), 33. 
He transferred that to the Security Branch of the police. BOSS was then renamed the Department of National Security (DONS) with Alec van Wyk as its new head. ${ }^{24}$

Then a professor of political science from the University of the Orange Free State, Professor Niel Barnard, was appointed in November 1979 to form a new intelligence service. Barnard, whose doctorate dissertation had been on the "Total Onslaught" of communism and decolonization against Apartheid in South Africa, would take over the South African Department of National Security (DONS) after the retirement of van Wyk. The now newly named National Intelligence Service (NIS) was announced on February 6, 1980. Barnard forced the retirement of many of the previous BOSS/DONS personnel. ${ }^{25}$

\section{The Fourth Reform: Micro-managing Intelligence}

By the early 1980s, South Africa under Apartheid was characterized by heightened repression, with intense surveillance of the domestic society and population. This was seen as required to maintain white control of the state and combat South Africa's non-white liberation movements banned in 1961. As the State of Emergency took effect in 1986, anti-apartheid activists were detained without trial, and hit squads eliminated scores of prominent activists. Legally sanctioned hit squads also conducted repeated assaults on neighboring countries against freedom fighter/ terrorist bases. ${ }^{26}$

Security policy and strategy were brought under the direct control of a State Security Council (SSC), chaired by the President. The SSC engaged in the micromanagement of intelligence implemented as a National Security Management System (NSMS) aimed to ensure a "total strategy" with white political control by "winning hearts and minds" (WHAM). The NSMS was structured down to the local level with Joint Management Committees (JMC's). The intelligence forces were from both the military (Civil Cooperation Bureau) and the police (Security Branch). This was not too different from BOSS's propaganda projects in the 1970 s, yet funding was independently audited. ${ }^{27}$

The Cold War ended in 1989, and Eastern Bloc forces withdrew from subSahara Africa, for example, East German and Cuban troops. By then, there were no European colonies in Africa. Without this external threat, the South African military lost its predominant influence over political life in the country. And so,

24 Maritz Spaarwater, A Spook's Progress: From Making War to Making Peace (Cape Town: Zebra Press, 2012), 87.

25 James M. Roherty, State Security in South Africa: Civil-military Relations Under P.W. Botha (New York: M. E. Sharpe, 1992), 107.

26 Harold Wolpe, Race, Class, and the Apartheid State (Trenton, NJ: Africa World Press, February 1990), 56-62.

27 Annette Seegers, "South Africa's National Security Management System, 1972-90," The Journal of Modern African Studies 29, no. 2 (June 1991): 253-273, https://doi.org/ 10.1017/S0022278X00002743. 
there was a need for further intelligence reforms. The NSMS, including the JMCS, was disbanded in 1989 by the last State President to preside over apartheid, President F.W. de Klerk. He reduced the SSC to an ordinary cabinet committee. ${ }^{28}$

\section{The Fifth Reform: Merging Apartheid and Opposition Intelligence Services}

The next catalyst determining intelligence reforms to replace the NSM and JMC system was in August 1991. A National Peace Accord was accepted by all the major political parties to disband apartheid and introduce democratization. The Convention for a Democratic South Africa (CODESA), convened in December 1991, would see fruition in the "Transitional Executive Authority (TEC) Act (1993)."

Based on the TEC Act, the Sub-Councils on Defense, Law and Order, and on Intelligence were established. The Sub-Council on Intelligence proposed the creation of a national capability from the amalgamation of six disparate intelligence entities (Apartheid services, the liberation movements, and the former Bantustan states of Transkei, Ciskei, Venda, and Bophuthatswana) into two new civilian intelligence structures. ${ }^{29}$

The subsequent "White Paper on Intelligence (1994)," produced by the transitional government, was tasked with defining how to interpret and translate a broad definition of security into intelligence functions. Clearly influenced by the Infogate scandal, it determined the role of intelligence would be based on a premise written in Section 3.3, "Towards a new national security doctrine that would have emphasis on 'transparency and accountability.' In short, democratisation ensures 'good governance.'"' 30

Further, the White Paper provided the policy framework for the development of the intelligence structures, which included domestic and foreign intelligence, military intelligence, and crime intelligence, as well as a mechanism for coordination (National Intelligence Coordinating Committee) and mechanisms for control and oversight, especially of the use of state funds. So that there could be no misunderstanding, Annexure A, "The Code of conduct for intelligence workers" was stipulated as (8) "Shall commit themselves to carry out their duties without

28 Robert D'A. Henderson, "South African Intelligence Transition from de Klerk to Mandela: An Update," International Journal of Intelligence and CounterIntelligence 8, no.4 (1995): 471-485, https://doi.org/10.1080/08850609508435299.

29 Timothy D. Sisk, "South Africa's National Peace Accord," Peace \& Change: A Journal of Peace Research 19, no. 1 (January 1994): 50-70, https://doi.org/10.1111/j.14680130.1994.tb00598.x.

30 South African Government, "Intelligence White Paper, 1994," accessed September 1, 2020, https://www.gov.za/documents/intelligence-white-paper. 
seeking personal gain or advantage by reason of the duties, facilities, funds, and knowledge entrusted to them. ${ }^{31}$

\section{The Sixth Reform: Creating Post-Apartheid Intelligence Services}

In 1994, "one-man, one-vote democracy" was introduced in South Africa, thereby abolishing apartheid. The all-white National Party that had been in power since 1948 lost to the African National Congress, which has ruled since. There was no longer the external threat of the Cold War and Eastern Bloc forces in Africa supporting decolonization or an internal threat of militant anti-Apartheid forces. With this came commissions of inquiry into the intelligence services, the role the services play in the government, and how they help shape government policy.

The same essential procedures for overcoming challenges and issues that Prime Minister Botha had applied in 1978 to terminate BOSS after the Infogate scandal were also applied by the new President Nelson Mandela in 1994, as South Africa's first non-white President. These were a review of the means to meet the needs, a change in the security and intelligence services' structure to serve this, a change in those heading them, legislation to ensure checks and safeguards, and a structure for independent auditing of finances.

Democratization led the process where the "South Africa Constitution (1994)" reflects key departure points for all the security services in Article 198 (4) "The security services must be structured and regulated by national legislation." And following this Article 210, "the coordination of all intelligence services; and civilian monitoring of the activities of those services by an Inspector appointed by the President." 32

In conforming to this, the "National Strategic Intelligence Act (1994)" brought into existence two civilian intelligence services, one for domestic intelligence, the National Intelligence Agency (NIA), and another for foreign intelligence, the South African Secret Service (SASS). ${ }^{33}$

To ensure accountability and transparency of these, in the Parliamentary process that debates and votes on the annual budget for the state, multi-party parliamentary committees were formed. Their purpose was to execute legislative oversight of the intelligence domain, including the use of state funds. In addition, various mechanisms were created by the "Intelligence Services Oversight Act (1994)," for example, the Joint Standing Committee on Intelligence (JSCI), and

31 South African Government, "Intelligence White Paper, 1994."

32 South African Government, The Constitution of the Republic of South Africa, 1996, accessed September 1, 2020, https://www.justice.gov.za/legislation/constitution/ SAConstitution-web-eng.pdf.

33 South African Government "National Strategic Intelligence Act, 1994," accessed September 1, 2020, https://www.gov.za/sites/default/files/gcis_document/201409/ act39of1994.pdf. 
the Inspector General (appointed by the President after nomination by the JSCl and approved by Parliament). ${ }^{34}$

Due to the trauma of the Infogate scandal, where the undue closeness of individuals led to the misuse of state funds, the Act created the National Intelligence Coordinating Committee. Among other things, it would oversee the use of funds and would report to the whole Cabinet. It would also prioritize intelligence activities within the intelligence community. ${ }^{35}$

Lessons gained from the Infogate trauma, where BOSS and Military Intelligence (MI) had clashed, were incorporated into the "White Paper on Defense (1996)." Section 1.1 places emphasis on "openness and accountability." Section 11.2 obligates defense intelligence services to the same legislation as non-military intelligence services and so too to accountability and transparency, including for the use of state funds. Section 4 gives the Joint Standing Committee on Defense and the Joint Standing Committee on Intelligence in Parliament oversight powers on intelligence. ${ }^{36}$

In 1996, to prevent the situation whereby BOSS had dominated, as one agency, all domestic as well as foreign intelligence and also domestic security and given its abuse of citizens, the "National Crime Prevention Strategy (NCPS) (1996)" implemented changes within the intelligence structures for crimes. All ongoing criminal intelligence actions involving the police, the defense forces, the National Intelligence Coordination Committee, and the Departments of Justice, Correctional Services and Welfare would be separate but coordinated and also collaborate with the NIS, the SASS, academic analysts, and NGO's. ${ }^{37}$

Given the corruption exposed in the Infogate scandal, where the entire intelligence apparatus had been in the hands of only two people-the Prime Minister and Director of BOSS - now the two civilian agencies (NIA and SASS) and the intelligence units of police and defense forces would be driven by the Minister of Intelligence acting in consultation with the Minister of Defense and the Minister of Safety and Security. Further, an additional position, a Coordinator for Intelligence, was created with responsibilities for coordinating the supply of intelligence by the different agencies to intelligence clients. ${ }^{38}$

34 South African Government, "Intelligence Services Oversight Act 40 of 1994," https://www.gov.za/documents/committee-members-parliament-and-inspectorsgeneral-intelligence-act.

35 "National Intelligence Coordinating Committee [NICOC]," globalsecurity.org, accessed September 10, 2020, https://www.globalsecurity.org/intell/world/rsa/nicoc.htm.

36 South African Government, "White Paper on Defence, 1996 \& Defence Review, 1996," accessed September 10, 2020, https://static.pmg.org.za/docs/2004/appendices/040 817wpaper.htm.

37 South African Government, "National Crime Prevention Strategy: Summary," accessed September 1, 2020, https://www.gov.za/documents/national-crime-preventionstrategy-summary.

38 South Africa Government "National Strategic Intelligence Act." 
When there is cause for concern, then a Ministerial Review Commission on Intelligence can be convened. An example of this was the abuse of position within the National Intelligence Agency in 2006. The report of the Commission was released to the public in September 2008. ${ }^{39}$

\section{Conclusion}

The hypothesis of this article was that intelligence reform and intelligence sector reform are the result of traumatic catalyst rather than gradual evolution, reactionary rather than proactive, and are not quick. The threat environment, an emergency, another necessity, e.g., democratization, gross failure, and scandals, are causes for reforms.

The case examined was South African intelligence services. South Africa is significant due to diverse and constantly changing operational environments: the Cold War, decolonization of Africa, Apartheid, post-Cold War, and postApartheid democratization. From the first non-military intelligence agency created in 1968, the Bureau of State Security, it was clear that the nature of intelligence requires striking a fine balance between security, secrecy, transparency, and accountability. The relationship between appointed and elected officials, the Prime Minister and the Bureau's Director, was too close, and state funds were misused.

The uncovering of the misuse of state funds, the Infogate scandal (1978), influenced intelligence reforms and intelligence sector reforms for the subsequent 20 years. The reforms examined were legislation, jurisdictions, restructuring, micro-managing intelligence, merging apartheid and opposition intelligence services, and creating post-Apartheid intelligence services. An important legacy from the Infogate scandal was that each reform included mechanisms, structures, and legislation to implement accountability and transparency to ensure that state funds would not be misused again.

Democratization, abolishing apartheid, and a "one-man, one-vote democracy" achieved in 1994 added weight to the reforms. Democratized South Africa post-Cold War has a remarkably reformed intelligence services sector vastly in contrast to that of the Cold War and Apartheid that was militarized, highly repressive, and focussed as an instrument of population control

There are no good sources about the future. It would be a mistake to assume that everything about the South African experience is relevant to the experiences of other countries. Yet several lessons can be drawn: every reform is unique and almost never easy, operationalizing any changes, including legislative mandates of transformation, is more complex than anticipated, and while the process to be addressed in reform starts with reflecting the envisaged ideal situation, the outcome is not always as expected.

39 Lauren Hutton, "Overview of the South African Intelligence Dispensation," Intelligence Studies at the Research Institute for European and American Studies, November 22, 2008, www.rieas.gr/images/HOUTONSA.pdf. 
South Africa's case shows that reforms of intelligence and the intelligence sector are iterative with the democratization process and that reform should begin earlier rather than later in the overall progression of democratization. The process of reforms to be addressed starts by convening reviews, commissions of inquiry, or ministerial task teams. Then legislation by defining the security vision and framework in law, followed by marketing the new elements to all, accelerating reforms, developing or strengthening managerial ability, providing clear guidance, insisting on accountability and financial transparency and ensuring parliamentary oversight, instituting procedures for authorizing operations, and confirming the legality of operations. Above all, errors can be avoided by not making uncoordinated, piecemeal changes.

\section{Disclaimer}

The views expressed are solely those of the author and do not represent official views of the PfP Consortium of Defense Academies and Security Studies Institutes, participating organizations, or the Consortium's editors.

\section{Acknowledgment}

Connections: The Quarterly Journal, Vol. 20, 2021, is supported by the United States government.

\section{About the Author}

Dr. Glen Segell (FRGS) is a Research Fellow at the University of the Free State, South Africa, and a Research Fellow at the University of Haifa, Israel. He was born in South Africa and educated to a BA and MA at the Hebrew University Jerusalem and to a DPhil at the University of Oxford. He also holds editorial, research, and teaching positions in the United Kingdom. He specializes in intelligence studies, civil-military relations, and strategic communication and consults as an expert for NATO, holding the rank of Brigadier-General (Reserves). He was involved in active security and intelligence operations, including Psychological Warfare in Iraq, Kuwait, Sudan, and Libya. He has published a substantial number of peerreviewed articles and books. E-mail: glen@segell.com https://orcid.org/0000-0002-4186-2761 